Journal of Applied Pharmaceutical Science Vol. 6 (11), pp. 075-080, November, 2016

Available online at http://www.japsonline.com

DOI: $10.7324 / \mathrm{JAPS} .2016 .601112$

ISSN 2231-3354 (cc) BY-NC-SA

\title{
Styrax camporum and S. ferrugineus fruits: norneolignans, antioxidant and cytotoxic activities
}

Thais de Almeida Silva, Evelise Martins Polo, Camila Yamasita Henrique, Osvaine Júnior Alvarenga Alves, Heloiza Diniz Nicolella, Valéria Maria Melleiro Gimenez, Alba Regina Barbosa Araújo, Denise Crispim Tavares, Márcio Luís Andrade e Silva, Wilson Roberto Cunha, Ana Helena Januário, Patricia Mendonça Pauletti*

Center for Research in Exact and Technological Sciences, University of Franca, Franca, Brazil.

\section{ARTICLE INFO}

Article history:

Received on: 12/08/2016

Revised on: 03/10/2016

Accepted on: 24/10/2016

Available online: 29/11/2016

Key words:

Styrax camporum; Styrax

ferrugineus, DPPH,

cytotoxicity.

\begin{abstract}
The present study evaluated the antioxidant and cytotoxic activities of the methanol extract of Styrax camporum and S. ferrugineus fruits. Purification of both extracts, which displayed weak antioxidant and cytotoxic activities, resulted in isolation of seven compounds: homoegonol (1), egonol (2), demethoxy egonol-2methylbutanoate (3), egonol gentiobioside (4), demethoxy egonol (5), demethoxy homoegonol (6), and egonol2-methylbutanoate (7). XTT cell culture and DDPH assays helped to assess the activity of the pure compounds. Compared to gallic acid at $66.7 \mu \mathrm{g} / \mathrm{mL}$, the evaluated norneolignans were inactive in the DPPH assay. The cytotoxicity assay revealed that egonol acetate and compound $3 \mathrm{had} \mathrm{CC}_{50}$ of 267.90 and $19.10 \mu \mathrm{g} / \mathrm{mL}$ at $24 \mathrm{~h}$. Compound 3 was also assayed on cancer cells lines (HeLa, MO59J and MCF-7), but it did not reduce the viability of these cells with the same efficiency. Again, the results presented here confirmed that the egonol core is a promising structural feature for anticancer drug research.
\end{abstract}

\section{INTRODUCTION}

A diet that advocates fruits intake has long been recognized as an ally in promoting health and preventing disease. Such diet reduces the risk of chronic diseases such as cancer, diabetes, cardiovascular disease, and arthritis. Indeed, fruits are normally rich in antioxidants, like tannins, stilbenes, flavonoids, and phenolic acids (Kozłowska and Szostak-Wegierek, 2014; Zhang et al., 2015). Several fruits with high potential for agriculture are native to the Brazilian cerrado. Local people have traditionally consumed these fruits, which display high nutritional and economic potential (Siqueira et al., 2013; Agostini-Costa et al., 2006). In fact, the nutritional value of these fruits has led to their increasing consumption nationalwide and worldwide (Rufino et al., 2010). In addition, these fruits present high antioxidant capacity and prominent phenolic content

\footnotetext{
* Corresponding Author

E-mail: patrpaul @ gmail.com
}

(Cândido et al., 2015; Siqueira et al., 2013; Rocha et al., 2011; Silva et al., 2008). Styrax camporum Pohl and Styrax ferrugineus Ness et. Mart. are two species that occur in the Brazilian cerrado. However, no research on the chemical and biological potential of their fruits has been conducted. Existing studies on S. camporum and $S$. ferrugineus have been limited to their leaves and barks (Francielli de Oliveira et al., 2012; Braguine et al., 2012; Teles et al., 2005; Bacchi and Sertié, 1995; Pauletti et al., 2000). In indigenous medicine, S. camporum and S. ferrugineus have been employed in the treatment of gastrointestinal diseases and fever, respectively (Lorenzi, 1982; Rodrigues and Carvalho, 2008). The two species produce a resinous material that is secreted when the barks and trunks are injured by sharp objects, and this material can be used in place of benzoin resin, which presents antiinflammatory actions (Silva-Júnior and Pereira, 2009; de Almeida et al., 1998). Additionally, the fruits of $S$. ferrugineus are used in homemade jams (Silva-Júnior, 2012). Furthermore, the fruits of $S$. camporum feed also the wild animals, and have slightly sweet taste (Silva-Junior and Pereira, 2009; Kuhlmann 2012). 
Recently, LC-MS analysis of the fruits of $S$. ramirezii, from Mexico, accomplished by Timmers et al. (2015) has enabled their chemical characterization and determination of their antioxidant and anti-inflammatory activities. These authors also evaluated the compounds isolated from these fruits, egonol and homoegonol, in the bioassays. The results suggested that the inclusion of $S$. ramirezii fruits in the diet contributes with antioxidant and anti-inflammatory compounds intake.

Considering the need to understand native fruits better, we have assayed the methanol crude extract of Styrax camporum and S. ferrugineus fruits in the presence of DPPH (2,2-diphenyl-1picrylhydrazyl) and evaluated their cytotoxicity. We have also investigated the chemical composition and antioxidant and cytotoxicity properties of the isolated compounds.

\section{MATERIAL AND METHODS}

\section{General}

${ }^{1} \mathrm{H}$ and ${ }^{13} \mathrm{C}$ NMR spectra were recorded in $\mathrm{CDCl}_{3}$ or DMSO- $d_{6}$ on a Bruker AVANCE DRX 500 or on a Bruker DPX400 spectrometer (Bruker Corporation, USA); TMS was used as internal standard. HPLC was accomplished on a Shimadzu LC6AD system (Kyoto, Japan) equipped with a DGU-20A5 degasser, an SPD-20A series UV-VIS detector or an SPDM-20A series PDA detector, a CBM-20A communication bus module, a Reodyne manual injector, and LCsolution software. The columns and precolumns were SHIMADZU Shim-pack ODS (particle diameter 5 $\mu \mathrm{m}, 250 \times 4.60 \mathrm{~mm}$, and $250 \times 20 \mathrm{~mm}$ ). The $\mathrm{MeOH}$ employed in the analyses was HPLC grade, J. T. Baker. Direct-Q UV3 system, Millipore was used to obtain ultrapure water. Silica gel 60 (230-400 mesh, Sigma-Aldrich) was employed for column chromatography, and silica on TLC Al foils with fluorescent indicator $254 \mathrm{~nm}$ (Sigma-Aldrich) was also used. Prep-TLC was conducted on silica gel type G (SigmaAldrich).

\section{Fruit Material}

The fruits of Styrax camporum Pohl were collected at the campus of the University of São Paulo, Pirassununga, SP, Brazil, in February 2013, and the fruits of S. ferrugineus Ness et. Mart. were collected at Santa Cecilia, Patrocínio Paulista, SP, Brazil, in October 2012. The materials were identified by Prof. V.M.M. Gimenez and Prof. A.R.B. Araújo. Voucher specimens (SPFR 12170 and SPFR 12169, respectively) were deposited in the Herbarium of the Department of Biology, Faculdade de Filosofia Ciências e Letras de Ribeirão Preto, University of São Paulo, Brazil (Herbarium SPFR).

\section{Extraction and isolation}

The air-dried, powdered fruits (94.7 g) of S. ferrugineus were extracted with AcOEt, and then with $\mathrm{MeOH}$, yielding 8.8 and $8.6 \mathrm{~g}$ of crude extract, respectively. The solvents were selected based on previous work (Liu et al., 2011). The crude $\mathrm{MeOH}$ extract (MESF, $3.5 \mathrm{~g}$ ) was fractionated on a column chromatography on silica gel using a gradient of $n$-hexane/EtOAc as eluent, which afforded 66 fractions. In a previous study, our research group had purified the fractions 19-30 and 32-36 and obtained compounds 1 and 2 (de Oliveira et al., 2016). Fractions 12-13 yielded compound $3(12.9 \mathrm{mg})$ after Prep-TLC using $n$ hexane-EtOAc $(9: 1, v / v)$ as the mobile phase. Fraction 65 was purified by Prep-HPLC using $\mathrm{MeOH} / \mathrm{H}_{2} \mathrm{O}(60: 40, \mathrm{v} / \mathrm{v})$ as mobile phase, UV detection at $254 \mathrm{~nm}$, and $8 \mathrm{~mL} / \mathrm{min}$ flow rate were used, to yield five fractions. Fraction 3 gave compound 4 (54.8 $\mathrm{mg}, \mathrm{t}_{\mathrm{R}} 43.9 \mathrm{~min}$ ).

The air-dried, powdered fruits (63 g) of $S$. camporum were extracted with $\mathrm{MeOH}$, yielding $13.3 \mathrm{~g}$ of crude extract. The crude $\mathrm{MeOH}$ extract (MESC, $5 \mathrm{~g}$ ) was fractionated on a column chromatography on silica gel (70-230 mesh) by using a gradient of $n$-hexane/EtOAc as eluent, which afforded 59 fractions. Fractions 26-29, 30-32 and 43-46 furnished compounds 5, 1 and 2, respectively.

Fractions 33-39 were purified by using Prep-HPLC with $\mathrm{MeOH} / \mathrm{H}_{2} \mathrm{O}(80: 20, \mathrm{v} / \mathrm{v})$ as eluent, UV detection at $254 \mathrm{~nm}$, and 8 $\mathrm{mL} / \mathrm{min}$ flow rate, to yield three fractions. Fraction 2 gave compound $6\left(10 \mathrm{mg}, \mathrm{t}_{\mathrm{R}} 13.1 \mathrm{~min}\right)$. Fractions 13-19 were purified by using Prep-HPLC with $\mathrm{MeOH} / \mathrm{H}_{2} \mathrm{O}(85: 15$, v/v) as eluent, UV detection at $254 \mathrm{~nm}$, and $8 \mathrm{~mL} / \mathrm{min}$ flow rate, to yield nine fractions. Fraction 6 gave compound $7\left(10.3 \mathrm{mg}, \mathrm{t}_{\mathrm{R}} 36.7\right.$ $\min )$.

\section{Homoegonol (1).}

${ }^{1} \mathrm{H}-\mathrm{NMR}\left(\mathrm{CDCl}_{3}, 500 \mathrm{MHz}\right): \delta 7.46(1 \mathrm{H}, \mathrm{dd}, J=8.2$ and 1.8, H-6') $7.37\left(1 \mathrm{H}, \mathrm{d}, J=1.8, \mathrm{H}-2^{\prime}\right), 6.98(1 \mathrm{H}, \mathrm{br} \mathrm{s}, \mathrm{H}-4), 6.93$ $\left(1 \mathrm{H}, \mathrm{d}, J=8.2, \mathrm{H}-5^{\prime}\right) 6.84(1 \mathrm{H}, \mathrm{s}, \mathrm{H}-3), 6.64(1 \mathrm{H}, \mathrm{br} \mathrm{s}, \mathrm{H}-6), 4.04$ $\left(3 \mathrm{H}, \mathrm{s}, 7-\mathrm{OCH}_{3}\right), 3.99\left(3 \mathrm{H}, \mathrm{s}, 4^{\prime}-\mathrm{OCH}_{3}\right) 3.93\left(3 \mathrm{H}, \mathrm{s}, 3^{\prime}-\mathrm{OCH}_{3}\right)$, $3.71\left(2 \mathrm{H}, \mathrm{t}, J=6.0, \mathrm{H}-3^{\prime \prime}\right), 2.79 \mathrm{t}\left(2 \mathrm{H}, J=7.9, \mathrm{H}-1^{\prime \prime}\right), 1.96(2 \mathrm{H}, \mathrm{m}$, $\left.\mathrm{H}-2^{\prime \prime}\right)$.

\section{Egonol (2).}

${ }^{1} \mathrm{H}-\mathrm{NMR}\left(\mathrm{CDCl}_{3}, 500 \mathrm{MHz}\right): \delta 7.40(1 \mathrm{H}, \mathrm{dd}, J=8.0$ and 1.7, H-6'), $7.32\left(1 \mathrm{H}, \mathrm{d}, J=1.7, \mathrm{H}-2^{\prime}\right), 6.97(1 \mathrm{H}, \mathrm{d}, J=1.3, \mathrm{H}-4)$, $6.87\left(1 \mathrm{H}, \mathrm{d}, J=8.0, \mathrm{H}-5^{\prime}\right), 6.79(1 \mathrm{H}, \mathrm{s}, \mathrm{H}-3), 6.63(1 \mathrm{H}, \mathrm{d}, J=1.3$, $\mathrm{H}-6), \quad 6.01\left(2 \mathrm{H}, \quad \mathrm{s}, \quad \mathrm{OCH}_{2} \mathrm{O}\right), 4.03\left(3 \mathrm{H}, \quad \mathrm{s}, 7-\mathrm{OCH}_{3}\right), 3.71$ $\left(2 \mathrm{H}, \mathrm{t}, J=6.3, \mathrm{H}-3^{\prime \prime}\right), 2.78\left(2 \mathrm{H}, \mathrm{t}, J=7.5, \mathrm{H}-1^{\prime \prime}\right), 1.94(2 \mathrm{H}, \mathrm{m}, \mathrm{H}-$ $\left.2^{\prime \prime}\right)$.

\section{7-Demethoxy egonol-2-methylbutanoate (3).}

${ }^{1} \mathrm{H}-\mathrm{NMR}\left(\mathrm{CDCl}_{3}, 500 \mathrm{MHz}\right): \delta 7.32(1 \mathrm{H}, \mathrm{d}, J=8.2, \mathrm{H}-$ 7), $7.30\left(1 \mathrm{H}, \mathrm{dd}, J=8.0\right.$ and $\left.1.7, \mathrm{H}-6^{\prime}\right), 7.26(1 \mathrm{H}, \mathrm{d}, J=1.3, \mathrm{H}-4)$, $7.23\left(1 \mathrm{H}, \mathrm{d}, J=1.7, \mathrm{H}-2^{\prime}\right), 7.00(1 \mathrm{H}, \mathrm{dd}, J=8.2$ and $1.3, \mathrm{H}-6), 6.81$ $\left(1 \mathrm{H}, \mathrm{d}, J=8.0, \mathrm{H}-5^{\prime}\right), 6.73(1 \mathrm{H}, \mathrm{s}, \mathrm{H}-3), 5.94\left(2 \mathrm{H}, \mathrm{s}, \mathrm{OCH}_{2} \mathrm{O}\right), 4.04$ $\left(2 \mathrm{H}, \mathrm{t}, J=6.0, \mathrm{H}-3^{\prime \prime}\right), 2.70\left(2 \mathrm{H}, \mathrm{t}, J=7.9, \mathrm{H}-1^{\prime \prime}\right), 2.30(1 \mathrm{H}, \mathrm{m}, \mathrm{H}-$ 2a), 1.92 (2H, m, H-2"), 1.61 (1H, m, H-3a), $1.41(1 \mathrm{H}, \mathrm{m}, \mathrm{H}-3 \mathrm{a})$, $1.07(3 \mathrm{H}, \mathrm{d}, J=7.0, \mathrm{H}-5 \mathrm{a}), 0.83(3 \mathrm{H}, \mathrm{t}, J=7.4, \mathrm{H}-4 \mathrm{a}) .{ }^{13} \mathrm{C} \mathrm{NMR}$ $\left(100 \mathrm{MHz}, \mathrm{CDCl}_{3}\right): \delta 176.8(\mathrm{C}=\mathrm{O}, \mathrm{C}-1 \mathrm{a}), 156.0(\mathrm{C}-2), 153.4(\mathrm{C}-$ 8), 148.1 (C-4'), 148.0 (C-3'), 135.9 (C-5), 129.5 (C-9), 124.8 (C1'), 124.5 (C-6), 120.0 (C-4), 119.1 (C-6'), 110.7 (C-7), 108.7 (C5'), 105.4 d (C-2'), $101.3\left(\mathrm{OCH}_{2} \mathrm{O}\right), 100.0(\mathrm{C}-3), 63.5\left(\mathrm{C}-3^{\prime \prime}\right), 41.1$ 
(C-2a), $32.1\left(\mathrm{C}-1^{\prime \prime}\right), 30.9\left(\mathrm{C}-2^{\prime \prime}\right), 26.8$ (C-3a), 16.7 (C-5a), 11.7 (C$4 a)$.

\section{Egonol gentiobioside (4).}

${ }^{1} \mathrm{H}-\mathrm{NMR}$ (DMSO- $\left.d_{6}, 500 \mathrm{MHz}\right): \delta 7.40(1 \mathrm{H}, \mathrm{dd}, J=8.0$ and 1.5, H-6'), $7.43 \mathrm{~d}\left(1 \mathrm{H}, \mathrm{d}, J=1.5, \mathrm{H}-2^{\prime}\right), 7.00(1 \mathrm{H}, \mathrm{br} \mathrm{s}, \mathrm{H}-4)$, $7.21(1 \mathrm{H}, \mathrm{s}, \mathrm{H}-3), 7.03\left(1 \mathrm{H}, \mathrm{d}, J=8.0, \mathrm{H}-5^{\prime}\right), 6.78(1 \mathrm{H}, \mathrm{br} \mathrm{s}, \mathrm{H}-6)$, $6.09\left(2 \mathrm{H}, \mathrm{s}, \mathrm{OCH}_{2} \mathrm{O}\right), 4.21\left(1 \mathrm{H}, \mathrm{d}, J=7.5, \mathrm{H}-1^{\prime \prime \prime \prime}\right), 4.12(1 \mathrm{H}, \mathrm{d}, J=$ 7.9, H-1"'), $3.94\left(3 \mathrm{H}, \mathrm{s}, 7-\mathrm{OCH}_{3}\right), 3.92\left(1 \mathrm{H}, \mathrm{d}, J=10.4, \mathrm{H}-6^{\prime \prime \prime}\right)$, $3.79\left(1 \mathrm{H}, \mathrm{m}, \mathrm{H}-3^{\prime \prime}\right), 3.68\left(1 \mathrm{H}, \mathrm{dd}, J=11.2\right.$ and $\left.5.3, \mathrm{H}-6^{\prime \prime \prime \prime}\right), 3.54$ $\left(1 \mathrm{H}, \mathrm{dd}, J=10.4\right.$ and $\left.6.4, \mathrm{H}-6^{\prime \prime \prime}\right), 3.43\left(1 \mathrm{H}, \mathrm{m}, \mathrm{H}-3^{\prime \prime}\right), 3.27(2 \mathrm{H}, \mathrm{m}$, $\mathrm{H}-4^{\prime \prime \prime \prime}$ and $\left.\mathrm{H}-5^{\prime \prime \prime \prime}\right), 3.14\left(2 \mathrm{H}, \mathrm{t}, J=8.5, \mathrm{H}-5^{\prime \prime \prime}\right.$ and $\left.\mathrm{H}-3^{\prime \prime \prime \prime}\right), 3.08(2 \mathrm{H}$, $\mathrm{t}, J=8.5, \mathrm{H}-3^{\prime \prime \prime}$ and $\left.\mathrm{H}-4^{\prime \prime \prime}\right), 2.98$ (3H, m, H-6"'", H-2"' and H-2"''), $2.72\left(2 \mathrm{H}, \mathrm{m}, \mathrm{H}-1^{\prime \prime}\right), 1.86\left(2 \mathrm{H}, \mathrm{m}, \mathrm{H}-2^{\prime \prime}\right) .{ }^{13} \mathrm{C}$ NMR $(125 \mathrm{MHz}$, DMSO- $\left.d_{6}\right): \delta 156.0(\mathrm{C}-2), 149.0\left(\mathrm{C}-4^{\prime}\right), 148.0\left(\mathrm{C}-3^{\prime}\right), 145.2(\mathrm{C}-7)$, 142.0 (C-8), 138.0 (C-5), 131.0 (C-9), 125.0 (C-1'), 119.6 (C-6'), 113.0 (C-4), 109.7 (C-5'), 108.7 (C-6), 105.8 (C-2'), 104.9 (C-1"'"'), $103.7\left(\mathrm{C}-1^{\prime \prime \prime}\right), 102.3\left(\mathrm{OCH}_{2} \mathrm{O}\right), 102.0(\mathrm{C}-3), 77.5\left(\mathrm{C}-3^{\prime \prime \prime}, \mathrm{C}-5^{\prime \prime \prime}\right.$ and

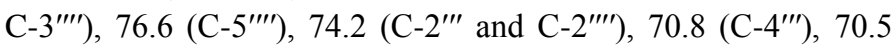
$\left(\mathrm{C}-4^{\prime \prime \prime \prime}\right), 69.2\left(\mathrm{C}-6^{\prime \prime \prime}\right), 68.7\left(\mathrm{C}-3^{\prime \prime}\right), 66.5\left(\mathrm{C}-6^{\prime \prime \prime \prime}\right), 56.6\left(7-\mathrm{OCH}_{3}\right)$ $32.7\left(\mathrm{C}-1^{\prime \prime}\right), 32.3\left(\mathrm{C}-2^{\prime \prime}\right)$.

\section{Demethoxy egonol (5).}

${ }^{1} \mathrm{H}-\mathrm{NMR}\left(\mathrm{CDCl}_{3}, 500 \mathrm{MHz}\right): \delta 7.37(1 \mathrm{H}, \mathrm{d}, J=8.0, \mathrm{H}-$ 7), $7.35\left(1 \mathrm{H}, \mathrm{d}, J=8.0, \mathrm{H}-5^{\prime}\right), 7.34(1 \mathrm{H}, \mathrm{d}, J=1.6, \mathrm{H}-4), 7.28(1 \mathrm{H}$, d, $\left.J=1.6, \mathrm{H}-2^{\prime}\right), 7.07(1 \mathrm{H}$, br d, $J=8.0, \mathrm{H}-6), 6.86(1 \mathrm{H}, \mathrm{dd}, J=8.0$ and 1.6, H-6'), $6.77(1 \mathrm{H}, \mathrm{s}, \mathrm{H}-3), 5.98\left(2 \mathrm{H}, \mathrm{s}, \mathrm{OCH}_{2} \mathrm{O}\right), 3.66(2 \mathrm{H}, \mathrm{t}$, $\left.J=6.2, \mathrm{H}-3^{\prime \prime}\right), 2.77$ (2H, t, $\left.J=7.2, \mathrm{H}-1^{\prime \prime}\right), 1.91\left(2 \mathrm{H}, \mathrm{m}, \mathrm{H}-2^{\prime \prime}\right) .{ }^{13} \mathrm{C}$ NMR (100 MHz, CDCl $)$ : $\delta 155.9(\mathrm{C}-2), 153.3(\mathrm{C}-8), 148.1\left(\mathrm{C}-3^{\prime}\right)$, 148.0 (C-4'), 136.4 (C-5), 129.5 (C-9), 124.8 (C-1'), 124.6 (C-6), 120.0 (C-4), 119.0 (C-5'), 110.7 (C-7), 108.6 (C-6'), 105.4 (C-2'), $101.3\left(\mathrm{O}-\mathrm{CH}_{2}-\mathrm{O}\right), 100.0(\mathrm{C}-3), 62.1\left(\mathrm{C}-3^{\prime \prime}\right), 34.7\left(\mathrm{C}-2^{\prime \prime}\right), 31.9(\mathrm{C}-$ 1 ).

\section{Demethoxy homoegonol (6).}

${ }^{1} \mathrm{H}-\mathrm{NMR}\left(\mathrm{CDCl}_{3}, 500 \mathrm{MHz}\right): \delta 7.41(1 \mathrm{H}, \mathrm{dl}, J=8.0, \mathrm{H}-$ 6), $7.41(1 \mathrm{H}$, br d, $J=8.0, \mathrm{H}-6$ '), $7.36(1 \mathrm{H}, \mathrm{br} \mathrm{s}, \mathrm{H}-4), 7.36(1 \mathrm{H}, \mathrm{br}$ s, H-2') $7.10(1 \mathrm{H}, \mathrm{d}, J=8.0, \mathrm{H}-7), 6.93\left(1 \mathrm{H}, \mathrm{d}, J=8,0, \mathrm{H}-5^{\prime}\right), 6.85$ $(1 \mathrm{H}, \mathrm{s}, \mathrm{H}-3), 3.99\left(3 \mathrm{H}, \mathrm{s}, 4^{\prime}-\mathrm{OCH}_{3}\right), 3.93\left(3 \mathrm{H}, \mathrm{s}, 3^{\prime}-\mathrm{OCH}_{3}\right), 3.70$ $\left(2 \mathrm{H}, \mathrm{t}, J=6.2, \mathrm{H}-3^{\prime \prime}\right), 2.80\left(2 \mathrm{H}, \mathrm{t}, J=7.5, \mathrm{H}-1^{\prime \prime}\right), 1.94(2 \mathrm{H}, \mathrm{m}, \mathrm{H}-$ $2^{2 \prime)}{ }^{13} \mathrm{C}$ NMR (100 MHz, $\left.\mathrm{CDCl}_{3}\right): \delta 156.0(\mathrm{C}-2), 153.4(\mathrm{C}-8)$, 149.5 (C-4'), 149.1 (C-3'), 136.4 (C-5), 129.6 (C-9), 124.6 (C-1'), 124.5 (C-6), 119.9 (C-4), 117.9 (C-6'), 111.3 (C-5'), 110.7 (C-7),

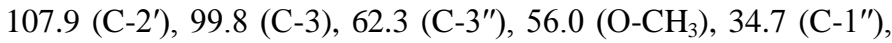
$32.0\left(\mathrm{C}-2^{\prime \prime}\right)$.

\section{Egonol-2-methylbutanoate (7).}

${ }^{1} \mathrm{H}-\mathrm{NMR} \quad\left(\mathrm{CDCl}_{3}, \quad 400 \quad \mathrm{MHz}\right): \quad \delta \quad 7.40 \quad(1 \mathrm{H}, \quad \mathrm{dd}$, $J=8.0$ and 2.0, H-6'), $7.32\left(1 \mathrm{H}, \mathrm{d}, J=2.0, \mathrm{H}-2^{\prime}\right), 6.95(1 \mathrm{H}, \mathrm{d}, J=$ 1.7, H-4), $6.87\left(1 \mathrm{H}, \mathrm{d}, J=8,0, \mathrm{H}-5^{\prime}\right), 6.79(1 \mathrm{H}, \mathrm{s}, \mathrm{H}-3), 6.60(1 \mathrm{H}$, d, $J=1.7, \mathrm{H}-6), 6.00\left(2 \mathrm{H}, \mathrm{s}, \mathrm{OCH}_{2} \mathrm{O}\right), 4.12\left(2 \mathrm{H}, \mathrm{t}, J=6.7, \mathrm{H}-3^{\prime \prime}\right)$, $4.03\left(3 \mathrm{H}, \mathrm{s}, 7-\mathrm{OCH}_{3}\right), 2.75\left(2 \mathrm{H}, \mathrm{t}, J=7.9, \mathrm{H}-1^{\prime \prime}\right), 2.39(1 \mathrm{H}, \mathrm{m}, \mathrm{H}-$ 2a), $1.98\left(2 \mathrm{H}, \mathrm{m}, \mathrm{H}-2^{\prime \prime}\right), 1.68 \mathrm{~m}(1 \mathrm{H}, \mathrm{m}, \mathrm{H}-3 \mathrm{a}), 1.49(1 \mathrm{H}, \mathrm{m}, \mathrm{H}-$ 3a), 1.16 (3H, d, $J=7.0, \mathrm{H}-5 \mathrm{a}), 0.92$ (3H, t, $J=7.3, \mathrm{H}-4 \mathrm{a})$.

\section{Acetylation of (1) and (2)}

Homogonol (1) and egonol (2) (5 mg) were dissolved in acetic anhydride $(3 \mathrm{~mL})$ and pyridine $(3 \mathrm{~mL})$. The mixture was allowed to react overnight. Then, cold $\mathrm{H}_{2} \mathrm{O}(30 \mathrm{~mL})$ was added, and the mixture was extracted with $\mathrm{CH}_{2} \mathrm{Cl}_{2}(2 \times 15 \mathrm{~mL}), \mathrm{HCl} 10 \%$ $(2 \times 15 \mathrm{~mL})$, and $\mathrm{H}_{2} \mathrm{O}(3 \times 15 \mathrm{~mL})$. Anhydrous sodium carbonate was added on to the organic phase, which was then filtered and concentrated under reduced pressure, to yield acetate derivatives 1a and $2 \mathbf{a}$.

\section{Homoegonol acetate (1a).}

${ }^{1} \mathrm{H}-\mathrm{NMR}\left(\mathrm{CDCl}_{3}, 500 \mathrm{MHz}\right): \delta 7.46(1 \mathrm{H}, \mathrm{dd}, J=2.0$ and 8.4, H-6') $7.37\left(1 \mathrm{H}, \mathrm{d}, J=2.0, \mathrm{H}-2^{\prime}\right), 6.97(1 \mathrm{H}, \mathrm{d}, J=1.2, \mathrm{H}-4)$, $6.93\left(1 \mathrm{H}, \mathrm{d}, J=8.4, \mathrm{H}-5^{\prime}\right), 6.84 \mathrm{~s}(1 \mathrm{H}, \mathrm{s}, \mathrm{H}-3), 6.61(1 \mathrm{H}, \mathrm{d}, J=1.2$, $\mathrm{H}-6), 4.13\left(2 \mathrm{H}, \mathrm{t}, J=7.8, \mathrm{H}-3^{\prime \prime}\right), 4.03\left(3 \mathrm{H}, \mathrm{s}, 7-\mathrm{OCH}_{3}\right), 3.93(3 \mathrm{H}, \mathrm{s}$, $\left.4^{\prime}-\mathrm{OCH}_{3}\right), 3.83\left(3 \mathrm{H}, \mathrm{s}, 3^{\prime}-\mathrm{OCH}_{3}\right), 2.76\left(2 \mathrm{H}, \mathrm{t}, J=7.5, \mathrm{H}-1^{\prime \prime}\right), 2.07$ $\left(3 \mathrm{H}, \mathrm{s}, 3^{\prime \prime}-\mathrm{COOCH}_{3}\right), 2.01\left(2 \mathrm{H}, \mathrm{m}, \mathrm{H}-2^{\prime \prime}\right)$.

\section{Egonol acetate (2a). \\ ${ }^{1} \mathrm{H}-\mathrm{NMR}\left(\mathrm{CDCl}_{3}, 500 \mathrm{MHz}\right): \delta 7.40(1 \mathrm{H}, \mathrm{dd}, J=1.6$ and 8.2, H-6'), $7.32\left(1 \mathrm{H}, \mathrm{d}, J=1.6, \mathrm{H}-2^{\prime}\right), 6.96(1 \mathrm{H}, \mathrm{d}, J=1.1, \mathrm{H}-4)$, $6.87\left(1 \mathrm{H}, \mathrm{d}, J=8.2, \mathrm{H}-5^{\prime}\right), 6.79(1 \mathrm{H}, \mathrm{s}, \mathrm{H}-3), 6.61(1 \mathrm{H}, \mathrm{d}, J=1.1$, $\mathrm{H}-6), 6.01\left(2 \mathrm{H}, \mathrm{s}, \mathrm{OCH}_{2} \mathrm{O}\right), 4.12\left(2 \mathrm{H}, \mathrm{t}, J=6.5, \mathrm{H}-3^{\prime \prime}\right), 4.01(3 \mathrm{H}, \mathrm{s}$, $\left.7-\mathrm{OCH}_{3}\right), 2.75\left(2 \mathrm{H}, \mathrm{t}, J=7.7, \mathrm{H}-1^{\prime \prime}\right), 2.00\left(2 \mathrm{H}, \mathrm{m}, \mathrm{H}-2^{\prime \prime}\right), 2.07(3 \mathrm{H}$, s, 3 "- $\mathrm{COOCH}_{3}$ ).}

\section{Cytotoxicity Assay}

The cytotoxicity of the extracts (MESF and MESC) and compounds (1a, 2a, 3, 4, 5, 6 and 7) was first assessed in the case of cell line GM07492A (normal human lung fibroblasts). Then, compound $\mathbf{3}$ was tested in the case of the cancer cell lines: human breast adenocarcinoma (MCF-7), human cervical adenocarcinoma (HeLa), and human glioblastoma (MO59J). The cell lines were maintained as monolayers in plastic culture flasks $\left(25 \mathrm{~cm}^{2}\right)$ containing HAM-F10 plus DMEM (1:1; Sigma-Aldrich), with $10 \%$ fetal bovine serum (Nutricell), $2.38 \mathrm{mg} / \mathrm{mL}$ Hepes (SigmaAldrich), $0.01 \mathrm{mg} / \mathrm{mL}$ streptomycin (Sigma-Aldrich), and 0.005 $\mathrm{mg} / \mathrm{mL}$ penicillin (Sigma-Aldrich), at $37^{\circ} \mathrm{C}$ and under humidified atmosphere with $5 \% \mathrm{CO}_{2}$. Cells from the fourth to the twelfth passage were used.

Cytotoxicity was measured by using the Colorimetric Assay In Vitro Toxicology, XTT Kit (Roche Diagnostics). Briefly, $1 \times 10^{4}$ cells were seeded in microplates containing $100 \mu \mathrm{L}$ of culture medium (1:1 HAM F10 + DMEM or DMEM alone) supplemented with $10 \%$ fetal bovine serum and concentrations of the tested extracts and compounds ranging from 1.25 to 2500 $\mu \mathrm{g} / \mathrm{mL}$. Negative (no treatment), solvent (0.02\% DMSO) and positive (25\% DMSO) controls were added to the microplate. After incubation at $36.5{ }^{\circ} \mathrm{C}$ for $24 \mathrm{~h}$, the culture medium was removed and the cells were washed with $100 \mu \mathrm{L}$ of PBS. Next, $100 \mu \mathrm{L}$ of culture medium HAM-F10 without phenol red was added. Then, $25 \mu \mathrm{l}$ of XTT were plated and incubated at $36.5{ }^{\circ} \mathrm{C}$ for $17 \mathrm{~h}$. The absorbance of the wells was determined at a wavelength of $450 \mathrm{~nm}$ and a reference length of $620 \mathrm{~nm}$ by using a 
multi-plate reader (ELISA - Tecan - SW Magellan vs 5.03 STD 2P).

\section{Antioxidant activity}

The antioxidant activity of crude extracts (MESF and MESC) and compounds was determined by using DPPH (2,2diphenyl-1-picrylhydrazyl). DPPH $(26.7 \mu \mathrm{g} / \mathrm{mL})$ dissolved in $\mathrm{MeOH}$ was added to the samples containing concentrations of the tested extracts/compounds ranging from $66.7-1.67 \mu \mathrm{g} / \mathrm{mL}$ in $\mathrm{MeOH}$. The mixture were incubated at room temperature, in the dark, for $30 \mathrm{~min}$. Remaining DPPH was determined at $517 \mathrm{~nm}$ in a microplate reader. The antioxidant activity was expressed by using values obtained as percent of scavenging calculated from the equation: $\%$ of scavenging $\left.=\left(\mathrm{A}_{\mathrm{DPPH}}-\mathrm{A}_{\text {sample }} / \mathrm{A}_{\mathrm{DPPH}}\right) * 100\right]$, where $\mathrm{A}_{\mathrm{DPPH}}$ is the absorbance of the solution with DPPH only, and $A_{\text {sample }}$ is the absorbance of the solution with extracts and compounds.

\section{Statistical analyses}

All the experiments were performed in triplicate, and the results are presented as the mean $\pm \mathrm{SD}$. The cytotoxicity effect was established based on the $\mathrm{CC}_{50}$ response parameter (cytotoxic concentration values that cause $50 \%$ cell growth inhibition for the different cell lines after $24 \mathrm{~h}$ of observation) calculated with the GraphPad Prism program. One-way analysis of variance (ANOVA) was used to compare the differences between the means; significance was set at $\mathrm{p}<0.05$.

\section{RESULTS AND DISCUSSION}

Free radicals are recognized as key intermediaries in several diseases like diabetes mellitus, cancer, liver diseases, renal failure, and degenerative diseases, caused by a deficient natural antioxidant protection mechanism. Thus, researches for beneficial bioactivities from plants are considered to be a rational approach in drug development (Roy et al., 2016). Additionally, fruits are known as super antioxidants and cancer protective agents, fruits are gaining attention for the exploration of their health improvement properties (Lim et al., 2007; Saini et al., 2014).

In this way, to establish the potential of the methanol crude extracts of $S$. ferrugineus (MESF) and of $S$. camporum (MESC) fruits, we screened the extracts for their antioxidant and cytotoxic activity in vitro (Table 1). The DPPH assay was selected due to its low-cost and easiness, and therefore has been used for the initial evaluation of the fruits extracts and isolated compounds antioxidant properties (Apak et al., 2016). The percentage of DPPH scavenging was 18.47 and 2.40 at $66.7 \mu \mathrm{g} / \mathrm{mL}$ for MESC and MESF, respectively. MESC afforded better antioxidant results as compared to MESF. Regarding the DPPH assay, the values obtained for the extracts were considered weak as compared to the positive control, gallic acid. This result could be explained in terms of the extraction procedure: we did not use acidified methanol to extract the polyphenol compounds (Timmers et al., 2015). In order to study the toxicological properties of the extracts we investigated the cytotoxicity on normal human lung fibroblast cells (GM07492A). The $\mathrm{CC}_{50}$ of MESC and MESF obtained in the assay was 270.8 and $164.7 \mu \mathrm{g} / \mathrm{mL}$, respectively. According to Suffness and Pezzuto (1990), only $\mathrm{CC}_{50}$ lower than $30 \mu \mathrm{g} / \mathrm{mL}$ indicates cytotoxic action. Hence, neither of the tested extracts displayed cytotoxicity, but MESF was more active than the MESF.

Purification of MESF and MESC led to the isolation of seven compounds (Figure 1): homoegonol (1), egonol (2), demethoxy egonol-2-methylbutanoate (3), egonol gentiobioside (4), demethoxy egonol (5), demethoxy homoegonol (6), and egonol-2-methylbutanoate (7). NMR spectroscopy helped to establish their chemical structures, which agreed with published data (Segal et al., 1967; Pauletti et al., 2000; Akgul and Anil, 2003; Takanashi et al., 1974; Lee et al., 2008; Takanashi and Takizawa, 2002; Takanashi and Takizawa, 1988).

Table 1: Antioxidant and cytotoxic activities of the extracts and norneolignans evaluated herein.

\begin{tabular}{ccccc}
\hline Samples & $\begin{array}{c}\text { DPPH } \\
\text { \% inhibition }\end{array}$ & \multicolumn{2}{c}{ CC $_{\mathbf{5 0}}(\boldsymbol{\mu g} / \mathbf{m L})$} \\
Cell lines
\end{tabular}

The values are the mean $\pm \mathrm{SD}, \mathrm{n}=3$.

DPPH (2,2-diphenyl-1-picrylhydrazyl).

$\mathrm{CC}_{50} 50 \%$ cytotoxic concentration values for the different cell lines after 24-h treatment.

GM07492A (Human lung fibroblasts), MCF-7 (human breast adenocarcinoma), MO59J (human glioblastoma) and HeLa (human cervical adenocarcinoma).

${ }^{a}$ Significantly different from treatment with $\operatorname{MESF}(p<0.001)$.

${ }^{\mathrm{b}}$ Significantly different from treatment with gallic acid $(p<0.001)$.

${ }^{\mathrm{c}}$ Significantly different from treatment with $\operatorname{MESC}(p<0.001)$. 

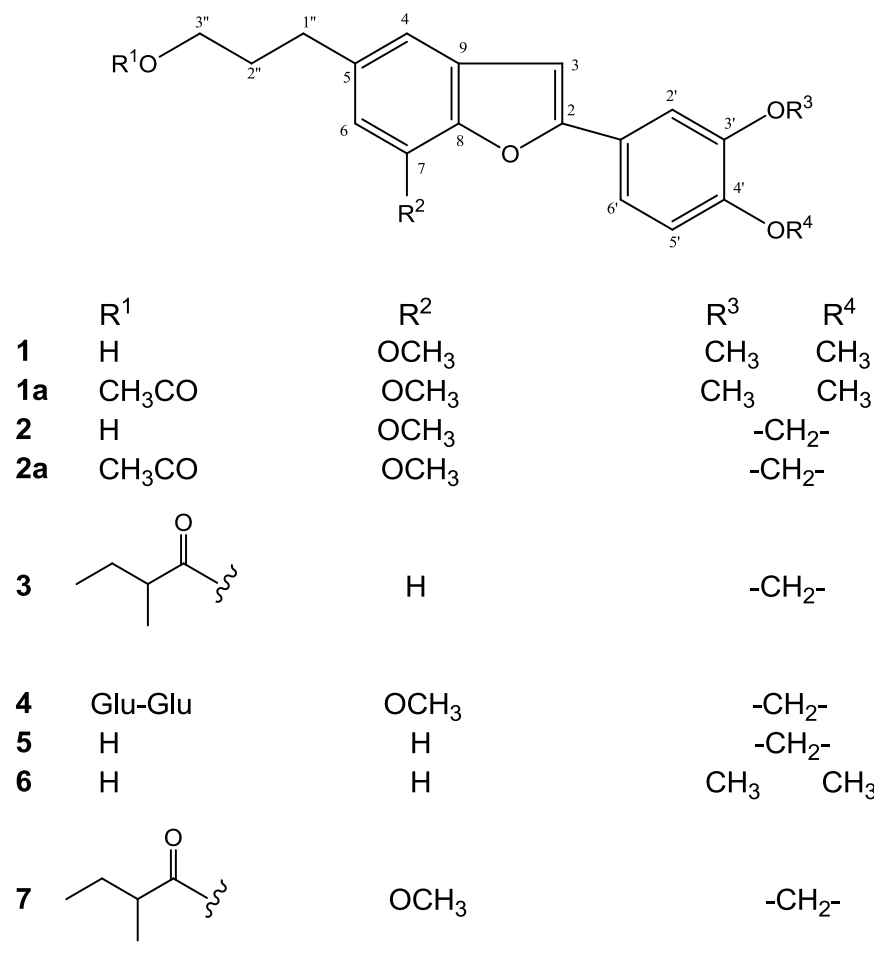

Fig. 1: Chemical structures of norneolignans.

Table 1 compiles the results achieved during the antioxidant assay of the isolated compounds. The evaluated norneolignans were inactive as compared to gallic acid at 66.7 $\mu \mathrm{g} / \mathrm{mL}$. According to the literature (Hou et al., 2003), the presence of compounds with stronger proton-donating capacity, such as phenolic compounds, is correlated to the DPPH scavenging activity. Based on our results, the compounds tested herein were almost inactive. The isolated compounds did not displayed free hydroxyl groups, so, the norneolignans contributed to the extracts weak antioxidant activities.

To ascertain the toxicological properties of the assessed compounds, we conducted a 24-h XTT trial on normal human lung fibroblast cells (GM07492-A). Table 1 outlines the $\mathrm{CC}_{50}$ values. Treatment of the normal cells with compounds 1a, 4, 5, 6 and 7 did not reduce cell viability significantly. These compounds were even less active than the MESC and MESF; e.g., compound 2a yielded $\mathrm{CC}_{50}$ of $267.90 \mu \mathrm{g} / \mathrm{mL}$, which showed it was less active than MESF.

Compound 3 had $\mathrm{CC}_{50}$ of $19.10 \mu \mathrm{g} / \mathrm{mL}$, giving the most promising $\mathrm{CC}_{50}$ among the evaluated norneolignas. To test the anticarcinogenic potential we used three cancer cells lines derived from different cancer types, human cervical adenocarcinoma (HeLa), human glioblastoma (MO59J), and human breast adenocarcinoma MCF-7 cells. For this reason, compound $\mathbf{3}$ was assayed on HeLa, MO59J, and MCF-7 cells, without effective reduction in cell viability.

The most active compounds (2a and $\mathbf{3}$ ) have quite similar chemical structure: both bear an egonol core. The difference between their structures lies on the presence of acetate at $\mathrm{R}^{1}$ in compound 2a, whereas 2-methylbutanoate exists at $\mathrm{R}^{1}$ and the methoxyl group at C-7 is absent in compound 3. De Oliveira et al. (2016) had already evaluated the action of homoegonol (1) and egonol (2) on normal human cell (GM07492A), murine melanoma (B16F10), human cervical adenocarcinoma (HeLa), human hepatocellular liver carcinoma (HepG2), human breast adenocarcinoma (MCF-7), and human glioblastoma (MO59J). The authors established that a combination of compounds $\mathbf{1}$ and $\mathbf{2}$ and compound 2 alone exhibited $\mathrm{CC}_{50}$ values lower than $30 \mu \mathrm{g} / \mathrm{mL}$ for MCF-7 and for HepG2 at $72 \mathrm{~h}$, respectively; selectivity indices were high.

Therefore, these authors suggested that the combination of compounds $\mathbf{1}$ and $\mathbf{2}$ as well as compound $\mathbf{2}$ alone should be a promising alternative for the development of anticancer drugs. In another study that used Kato III cells to evaluate drug cytotoxicity, egonol and demethoxy egonol presented in vitro cytotoxicity with $\mathrm{IC}_{50}$ values of 28.8 and $27.5 \mu \mathrm{g} / \mathrm{ml}$, respectively (Yoshikawa et al., 2001). These results again confirmed that the egonol core is a promising structural feature for anticancer drug research. According to Reiter et al. (2014), hybrids synthetized with egonol possess improved cytotoxic properties, thereby confirming the potential of the egonol structure in cancer research.

\section{CONCLUSION}

This is the first reported study on biological activities of fruits from $S$. camporum and $S$. ferrugineus. The present study provided evidence that the methanol extracts of $S$. camporum and S. ferrugineus fruits display weak antioxidant activity $(18.47 \%$, and $2.40 \%$ at $66.7 \mu \mathrm{g} / \mathrm{mL}$ ), as compared with the gallic acid at this same concentration. These results stemmed from the fact that the structure of the norneolignans present in these extracts do not bear a phenolic group. The extracts do not display cytotoxicity, either. The exception is compound $\mathbf{3}$, which proved to be cytotoxic to normal cells. However, compound $\mathbf{3}$ is not cytotoxicity to evaluated cancer cells. The isolated norneolignans could be used as starting material for synthesizing more cytotoxic compounds.

\section{ACKNOWLEDGEMENTS}

Financial support and sponsorship: The authors are grateful to the São Paulo Research Foundation (FAPESP) (Grant \# 2013/ 06164-5 and 2013/09280-6), Coordenadoria de Aperfeiçoamento de Pessoal do Ensino Superior (CAPES), and Conselho Nacional de Desenvolvimento Científico e Tecnológico (CNPq) for fellowships.

Conflict of Interests: There are no conflicts of interest.

\section{REFERENCES}

Agostini-Costa TdaS, da Silva DJ, Vieira RF, Sano SM. 2006. Espécies de maior relevância para a região Centro-Oeste. In: Vieira RF, Costa TSA, da Silva DB, Ferreira FR, Sano SM, ed. Frutas nativas da 
região Centro-Oeste. Brasília: Embrapa Recursos Genéticos e Biotecnologia 12-24.

Akgul YY, Anil H. Benzofurans and another constituent from seeds of Styrax officinalis. Phytochemistry, 2003; 63:939-943.

Apak R, Özyürek M, Güçlü K, Çapanoğlu E. Antioxidant Activity/Capacity Measurement. 2. Hydrogen Atom Transfer (HAT)Based, Mixed-Mode (Electron Transfer (ET)/HAT), and Lipid Peroxidation Assays. J Agric Food Chem, 2016; 64:1028-1045.

Bacchi EM, Sertié JA, Villa N, Katz H. Antiulcer action and toxicity of Styrax camporum and Caesalpinia ferrea. Planta Med, 1995; 61:204-207.

Braguine CG, Bertanha CS, Gonçalves UO, Magalhães LG, Rodrigues V, Melleiro Gimenez VM, Groppo M, Silva ML, Cunha WR, Januário AH, Pauletti PM.2012. Schistosomicidal evaluation of flavonoids from two species of Styrax against Schistosoma mansoni adult worms. Pharm Biol, 50;925-929.

Cândido TL, Silva MR, Agostini-Costa TS. Bioactive compounds and antioxidant capacity of buriti (Mauritia flexuosa L.f.) from the Cerrado and Amazon biomes. Food Chem, 2015; 177:313-319.

de Almeida SP, Proença CEB, Sano SM, Ribeiro JF.1998. Cerrado espécies vegetais úteis. Planaltina: Embrapa Recursos Genéticos e Biotecnologia.

de Oliveira PF, Damasceno JL, Bertanha CS, Araújo AR, Pauletti, PM, Tavares, DC. Study of the cytotoxic activity of Styrax camporum extract and its chemical markers, egonol and homoegonol. Cytotechnology, 2016; 68:1597-1602.

Francielli de Oliveira P, Furtado RA, Acésio NO, Leandro LF, Montanheiro G, de Pádua FC, Corrêa MB, Braguini CG, Pauletti PM, Tavares DC. In vivo protective activity of Styrax camporum hydroalcoholic extract against genotoxicity induced by doxorubicin and methyl methanesulfonate in the micronucleus and comet assays. Planta Med, 2012; 78:1899-1905.

Hou WC, Lin RD, Cheng KT, Hung YT, Cho $\mathrm{CH}$, Chen $\mathrm{CH}$, Hwang SY, Lee MH. Free radical-scavenging activity of Taiwanese native plants. Phytomedicine, 2003; 10:170-175.

Lee H-J, Park S-Y, Park S-Y, Lee OK, Jo HJ, Kang H-Y, Choi D-H, Paik K-H, Khan M. Benzofurans and sterol from the seeds of Styrax obassia. Chem Nat Compd, 2008; 44:435-439.

Kozłowska A, Szostak-Wegierek D. Flavonoids-food sources and health benefits. Rocz Panstw Zakl Hig, 2014; 65:79-85.

Kuhlmann M. 2012. Frutos e sementes do Cerrado atrativos para fauna: guia de campo. Brasília: Ed. Rede de sementes do Cerrado.

Lim YY, Lim TT, Tee JJ. Antioxidant properties of several tropical fruits: a comparative study. Food Chem, 2007;103:1003-1008.

Liu J, Dumontet V, Simonin AL, Iorga BI, Guerineau V, Litaudon M, Nguyen VH, Gueritte F. Benzofurans from Styrax agrestis as acetylcholinesterase inhibitors: structure-activity relationships and molecular modeling studies. J Nat Prod., 2011;74:2081-2088.

Lorenzi H. 1982. Árvores Brasileiras. Manual de identificação e cultivo de plantas arbóreas nativas do Brasil. São Paulo: Instituto Plantarum de Estudos da Flora.

Pauletti PM, Araújo AR, Young MCM, Giesbrecht AM, Bolzani VS. nor-Lignans from the leaves of Styrax ferrugineus (Styracaceae) with antibacterial and antifungal activity. Phytochemistry, 2000; 55:597-601.

Reiter C, Capci Karagöz A, Fröhlich T, Klein V, Zeino M, Viertel K, Held J, Mordmüller B, Emirdağ Öztürk S, Anil H, Efferth T, Tsogoeva SB. Synthesis and study of cytotoxic activity of 1,2,4-trioxaneand egonol-derived hybrid molecules against Plasmodium falciparum and multidrug-resistant human leukemia cells. Eur J Med Chem, 2014; 75:403412 .

Rocha WS, Lopes RM, da Silva DB, Vieira RF, da Silva JP, Agostini-Costa TdaS. Compostos fenólicos totais e taninos condensados em frutas nativas do Cerrado. Rev Bras Frutic, 2011; 33:1215-1221.

Rodrigues VEG, de Carvalho DA. Florística de plantas medicinais nativas de remanescentes de floresta estacional semidecidual na região do alto Rio Grande, Minas Gerais. Cerne, 2008; 14:93-112.
Roy S, Pawar S, Chowdhary A. Evaluation of In Vitro Cytotoxic and Antioxidant Activity of Datura metel Linn. and Cynodon dactylon Linn. Extracts. Pharmacognosy Res, 2016; 8:123-127.

Rufino MSM, Alves RE, Brito ES, Pérez-Jiménez J, SauraCalixto F, Mancini-Filho J. Bioactive compounds and antioxidant capacities of 18 non-traditional tropical fruits from Brazil. Food Chem, 2010; 121:996-1002.

Saini R, Dangwal K, Singh H, Garg V. Antioxidant and antiproliferative activities of phenolics isolated from fruits of Himalayan yellow raspberry (Rubus ellipticus). J Food Sci Technol, 2014; 51:33693375 .

Segal R, Milo-Goldzweig I, Sokoloff S, Zaitschek DV. A new benzofuran from the seeds of Styrax officinalis L. J Chem Soc C, 1967; 1967:2402-2404.

Silva-Júnior, MC da. 2012. 100 Árvores do Cerrado Sentido Restrito. Brasilia: Ed. Rede de sementes do Cerrado.

Silva-Júnior, MC da, Pereira, BAdaS. 2009. Mais 100 árvores do Cerrado. Matas de galleria. Guia de campo. Brasilia: Ed. Rede de sementes do Cerrado, 110 .

Silva MR, Lacerda DBCL, Santos GG, Martins DMO. Chemical characterization of native species of fruits from savanna ecosystem. Cienc Rural, 2008; 38:1790-1793.

Siqueira EMdA, Rosa FR, Fustinoni AM, de Sant'Ana LP, Arruda SF. Brazilian savanna fruits contain higher bioactive compounds content and higher antioxidant activity relative to the conventional red delicious apple. PLoS One, 2013; 8:e72826.

Suffness M, Pezzuto JM.1990. Assays related to cancer drug discovery. In: Hostettmann K, ed. Methods in Plant Biochemistry: Assays for Bioactivity. London: Academic Press 71-133.

Takanashi M, Takizawa Y. New benzofurans related to egonol from immature seeds of Styrax obassia. Phytochemistry, 1988; 27:12241226 .

Takanashi M, Takizawa Y. Isolation of new egonol compounds from seeds of Styrax japonica Sieb. Et Zucc. J Oleo Sci, 2002; 51:151155.

Takanashi M, Takizawa Y, Mitsuhashi T. 5-(3-Hydroxypropyl)2-(3',4' methylenedioxyphenyl)benzofuran. New benzofuran from Styrax obassia. Chem Lett, 1974; 8:869-871.

Teles HL, Hemerly JP, Paulettit PM, Pandolfi JR, Araujot AR, Valentini SR, Young MC, Bolzani VS, Silva DH. Cytotoxic lignans from the stems of Styrax camporum (Styracaceae). Nat Prod Res, 2005; 19:319323.

Timmers MA, Guerrero-Medina JL, Esposito D, Grace MH, Paredes-López O, García-Saucedo PA, Lila MA. Characterization of phenolic compounds and antioxidant and anti-inflammatory activities from Mamuyo (Styrax ramirezii Greenm.) fruit. J Agric Food Chem, 2015; 63:10459-10465.

Zhang YJ, Gan RY, Li S, Zhou Y, Li AN, Xu DP, Li HB. Antioxidant phytochemicals for the prevention and treatment of chronic diseases. Molecules, 2015; 20:21138-21156.

Yoshikawa K, Bando S, Arihara S, Matsumura E, Katayama S. A benzofuran glycoside and an acetylenic acid from the fungus Laetiporus sulphureus var. miniatus. Chem Pharm Bull, 2001; 49:327-329.

\section{How to cite this article:}

Silva TA, Polo EM, Henrique CY, Alves OJA, Nicolella HD, Gimenez VMM, Araújo ARB, Tavares DC, Silva MLA, Cunha WR, Januário AH, Pauletti PM. Styrax camporum and S. ferrugineus fruits: norneolignans, antioxidant and cytotoxic activities. J App Pharm Sci, 2016; 6 (11): 075-080. 